\title{
Kilka uwag w kwestii nowych hipotez na temat stanu zdrowia Gajusza Juliusza Cezara
}

Abstract

\section{A few remarks on the new hypotheses about the health of Gaius Julius Caesar}

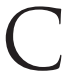
ountless works have been devoted to Gaius Julius Caesar. All the aspects of the leader's life have captured the interest of researchers. Information on the health condition of the famous politician was provided, among others, by Suetonius, Pliny the Elder, Appian of Alexandria, Plutarch of Cheronea and Cassius Dio. The preserved messages are highly fragmented, and their authors were not medics, which significantly affects the quality of the information. Nevertheless, the symptoms described by the ancients clearly indicate the health problems that Caesar had to deal with. The fragmentary nature of the descriptions and the lack of bone material make it impossible to clearly define which disease he suffered from. For this reason, a number of hypotheses have arisen regarding the causes described in the sources of attacks. The most popular were epilepsy, Meniere's disease, brain tumour, neurosyphilis, parasite infection and Hartnup disease. In recent years, celiac disease has also been mentioned. Due to the inability to test the "patient", all of them remain within the sphere of hypotheses, but today, taking into account the symptoms observed in Caesar, the most likely disease seems to be a brain tumour or a series of micro-haemorrhages. Hartnup disease seems to be an extremely interesting and probable option, but due to its hereditary nature, the problem should be investigated and discussed more broadly, taking into account the entire Julius family.

Keywords: Caesar, stroke, brain tumor, Hartnup disease, epilepsy, tuberculous meningitis, Meniere's disease, Taenia solium, coeliac disease 


\section{STRESZCZENIE}

ajuszowi Juliuszowi Cezarowi poświęcono niezliczoną liczbę prac. Wszystkie aspekty życia wodza budziły zainteresowanie badaczy. Informacje na temat stanu zdrowia słynnego polityka przekazali m.in. Swetoniusz, Pliniusz Starszy, Appian $z$ Aleksandrii, Plutarch $z$ Cheronei czy Kasjusz Dion. Zachowane relacje sa mocno fragmentaryczne, a ich autorzy nie byli medykami, co znaczacco wpływa na jakość przekazu. Niemniej opisane przez antycznych pisarzy objawy jasno wskazuja na problemy zdrowotne, $z$ którymi musiał się borykać Cezar. Fragmentaryczność opisów oraz brak materiału kostnego uniemożliwiaja jednoznaczne określenie, na jaka chorobę cierpiał słynny polityk. $Z$ tego powodu powstał szereg hipotez dotyczących przyczyn opisywanych w źródłach ataków. Wśród najpopularniejszych wymieniano epilepsję, chorobę Meniera, guz mózgu, neurosyfilis, zakażenie pasożytami czy chorobę Hartnupów. W ostatnich latach wspominano także o celiakii. Ze względu na brak możliwości przebadania „pacjenta” wszystkie pozostaja w sferze hipotez niemniej obecnie. Biorac pod uwage objawy zaobserwowane u Cezara, najbardziej prawdopodobną chorobą wydaje się guz mózgu lub seria mikroudarów. Niezwykle ciekawa i prawdopodobną opcją wydaje się choroba Hartnupów, ale ze względu na jej dziedziczny charakter problem należy przebadać i omówić szerzej, uwzględniając cały ród Juliuszów.

Słowa kluczowe: Cezar, udar, guz mózgu, choroba Hartnupów, epilepsja, gruźlica mózgu, choroba Meniera, Taenia solium, celiakia

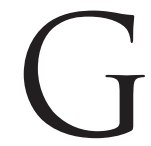

ajusz Juliusz Cezar, jeden $z$ najbardziej rozpoznawalnych ludzi świata antycznego, zdobył sławę jako znakomity wódz, polityk oraz pisarz ${ }^{1}$. Jego działalność i życie w ogóle było szczegółowo opisywane zarówno przez niego samego ${ }^{2}$, jak i przez licznych autorów starożytnych ${ }^{3}$. Pisarze antyczni przekazali informacje dotyczace nie tylko działalności politycznej i militarnej wodza, lecz także odnotowali wzmianki na temat jego podbojów miłosnych, słabości, wyglądu czy upodobañ ${ }^{4}$. Działalność militar-

1 T. Steven s on, Julius Caesar and the transformation of the Roman Republic, London-New York 2015; A. Ka m m, Julius Caesar. A Life, London-New York 2006; L. Canfora, Julius Caesar: People's Dictator, Edinburgh 2005; P. Freeman, Julius Caesar, New York 2008; Ch. Meie r, Caesar: A Biography, New York 1996; N. Caw th orne, Julius Caesar, London 2005; J. O s good, The Pen and the Sword: Writing and Conquest in Caesar's Gaul, "Classical Antiquity” 2009, vol. XXVIII, No. 2, s. 328-358; M. Gelze r, Caesar Politician and Statesman, Cambridge 1967.

${ }^{2}$ Cezar w swoich dziełach $O$ wojnie galijskiej oraz $O$ wojnie domowej. Por. Julius Caesar as Artful Reporter. The War Commentaries as Political Instruments, eds K. Welch, A. Powell, Swansea 1998.

${ }^{3} \mathrm{Na}$ temat Gajusza Juliusza Cezara pisali m.in. Swetoniusz, Plutarch z Cheronei, Kasjusz Dion, Appian z Aleksandrii, Wellejusz Paterkulus, Sallustiusz, Cyceron.

${ }^{4}$ Gajusz Juliusz Cezar ze względu na udział w życiu politycznym cieszył się dużym zainteresowaniem ze strony zarówno zwolenników, jak i wrogów. Owoco- 
na, ambicje oraz wpływ na ówczesną scenę polityczna powodowały, że niewiele aspektów życia Gajusza Juliusza Cezara umykało uwadze jego przyjaciół i wrogów.

Działalności politycznej i militarnej Cezara poświęcono niezliczona liczbę opracowań. W artykule chciałabym pochylić się nad znacznie mniej popularnym zagadnieniem dotyczacym stanu zdrowia jednego $z$ najsłynniejszych antycznych polityków. Bogaty materiał źródłowy dotyczacy jego osoby zawiera także fragmentaryczne, ale niezwykle ciekawe informacje dotyczace kwestii zdrowotnych. Na bazie tych wzmianek badacze doszli do wniosku, że słynny polityk cierpiał na epilepsję. Pogląd ten, przyjęty na podstawie wzmianek Swetoniusza ${ }^{5}$ i Plutarcha $z$ Cheronei ${ }^{6}$, był długo powtarzany w większości popularnych oraz naukowych tekstów poświęconych osobie Gajusza Juliusza Cezara ${ }^{7}$. W ostatnich kilkunastu latach badacze, biorąc pod uwage chronologię przekazów oraz aktualną wiedzę o etiologii różnego rodzaju chorób, zaczęli wątpić we wcześniej postawiona diagnozę. Na podstawie zachowanych informacji powstało wiele nowych hipotez dotyczacych przypadłości słynnego polityka ${ }^{8}$. Celem artykułu jest omówienie oraz weryfikacja wspó1czesnych hipotez dotyczacych zdrowia Cezara i ustalenie najbardziej prawdopodobnego schorzenia dajaccego objawy przedstawione w przekazach autorów antycznych.

wało to licznymi tekstami poświęconymi w całości lub fragmentarycznie osobie wodza. Zainteresowanie osoba Cezara nie osłabło także po jego śmierci ze względu na adopcję Oktawiana Augusta oraz rolę, jaka jego adoptowany syn odegrał w dziejach Rzymu.

${ }^{5}$ Suetonius, Divus Iulius 45.

${ }^{6}$ Plutarch, Caesar XVII.

7 B.-P. Don nadieu, La prétendue épilepsie de Jules César, „Mémoires de la Société Nationale des Antiquaries de France" 1937, t. LXXX, s. 27-36.

8 F.M. Galassi, H. Ashrafian, Julius Caesar's Disease: a new diagnosis, „Neurological Sciences” 2017, vol. XXXVIIII, s. 1-2. Por. e or und e m, Julius Caesar's Disease: a new diagnosis, London 2016; e orundem, Has the diagnosis of a stroke been overlooked in the symptoms of Julius Caesar? „Neurological Science" 2015, vol. XXXVI, s. 1521-1522; F.P. Retief, J.F.G. Cilliers, Julius Caesar (100-44 BC) - did he have a brain tumor?, "South African Medical Journal” 2010, vol. C, s. 26-28; T. Caw th or ne, Julius Caesar and the Falling Sickness, "Proceedings of the Royal Society of Medicine” 1957, vol. LI, s. 27-30; F. Bruschi, Was Julius Caesar's epilepsy due to neurocysteriosis?, „Trends in Parasitology" 2011, vol. XXVII, s. 373-374; J.G. Gomez, J.A. Kotler, J.B. Long, Was Julius Caesar's epilepsy due to a brain tumor?, „Journal of the Florida Medical Association" 1995, vol. LXXXII, s. 199-201; J.R. Hughes, Dictator Perpetuus: Julius Caesar - did he have seizures? If so, what was the etiology?, „Epilepsy and Behavior" 2004, vol. V, s. 756-764. 
Należy pamiętać, że głównym problemem badań dotyczących jednostek chorobowych dotykających postacie historyczne jest niemożność zbadania „pacjenta” lub jego szczątków. $Z$ tego powodu koniecznościa jest opieranie sie jedynie na niekompletnym opisie objawów sporządzonym przez autorów antycznych, którzy w większości przypadków nie byli medykami. $Z$ tego powodu, mimo ciagłego rozwoju nauki, pozostajemy jedynie w sferze hipotez, ponieważ nie mamy narzędzi umożliwiających ich pełną weryfikację.

Stosunkowo niewiele wiadomo na temat przodków Cezara, jego ojca, dalszych krewnych oraz ich stanu zdrowia. Jedna $z$ nielicznych wzmianek pochodzi $z$ pracy Pliniusza Starszego. Encyklopedysta wspomniał, że ojciec wodza oraz jeden $z$ jego krewnych zmarł nagle, bez żadnego ostrzeżenia ${ }^{9}$. Zapisana w Historia Naturalis informacja może sugerować istnienie w obrębie rodziny jakichś dziedzicznych problemów ze zdrowiem. Niespodziewana śmierć mężczyzn w sile wieku mogła być powodowana przebytym zawałem serca lub wylewem. Badacze wykazuja, że problemy zdrowotne występowały także u innych członków rodziny Gajusza Juliusza Cezara. Syn wodza i królowej Egiptu Kleopatry miał cierpieć na epilepsję. Co ciekawe, podobne problemy przypisywano także Brytannikowi, Kaliguli ${ }^{10}$ oraz innym przedstawicielom dynastii julijsko-klaudyjskiej ${ }^{11}$.

Na temat dzieciństwa Gajusza Juliusza Cezara także wiemy niewiele. Urodził się około 100 r. p.n.e. jako syn Gajusza Juliusza Cezara Starszego i Aurelii Kotty ${ }^{12}$. Jego młodość przypadała na burzliwe czasy konsulatu i tyranii Lucjusza Korneliusza Sulli ${ }^{13}$. Niewiele wiadomo na temat jego stanu zdrowia w tym okresie. W starszej literaturze można odnaleźć informację, że przyszły wódz miał przyjść na świat w wyniku cesarskiego cięcia. Prawdopodobnie

${ }^{9}$ Ojciec Gajusza Juliusza Cezara zmarł w Rzymie w 85 r. p.n.e. Do zgonu doszło w czasie zakładania sandałów. Por. Pliniu s, Historia Naturalis VII, 54.

${ }^{10}$ F. Bruschi, op. cit., s. 373. Por. D. Thomas Benediktson, Caligula's Phobias and Philias: Fear of Seizure?, "The Classical Journal” 1991, vol. LXXXVII, s. 159-163; R.S. Katz, The Illness of Caligula, „The Classical World” 1972, vol. LXV, s. 223-25; M.G. M or ga n, Caligula's Illness Again, "The Classical World” 1973, vol. LXVI, s. 327-329; A.T. Sandis o n, The Madness of the Emperor Caligula, „Medical History” 1958, vol. II, s. 202-209.

${ }_{11}$ C.H. Ferreira Camargo, H.A. Ghizoni Teive, Searching for neurological disease in the Julio-Claudian dynasty of the Roman Empire, „Arquivos Neuro-Psiquiatria" 2018, vol. LXXVI, No. 1, s. 53-57.

${ }_{12}$ P. Freeman, op. cit., s. 15.

${ }^{13}$ L. Telf ord, Sulla: A Dictator Reconsidered, London 2014. Por. A. Ke a ve n ey, Sulla the Last Republican, London-New York 2005. 
została ona zaczerpnięta $z$ pracy Pliniusza Starszego, który napisał: „Auspicatius enecta parente gignuntur, sicut Scipio Africanus prior natus primusque Caesarum a caeso matris utero dictus, qua de causa et Caesones apellati" ${ }^{14}$. Gdyby uznać prawdziwość tej informacji, można by się zastanawiać, czy wspominana często późniejsza „epilepsja” Cezara nie była wynikiem mikrouszkodzeń mózgu, do których mogło dojść na skutek trudnego porodu. Niemniej biorac pod uwage procedurę stosowaną w starożytnym Rzymie, praktycznie niemożliwe jest, by Cezar przyszedł na świat w ten sposób. Zgodnie $z$ zasadami religijnymi w Wiecznym Mieście nie można było pochować ciężarnej kobiety bez usunięcia płodu. $Z$ tego powodu zgodnie $z$ lex regia Numy Pompiliusza zabieg ten wykonywano w przypadku śmierci kobiety ${ }^{15}$. Aurelia Kotta - matka Cezara zmarła dopiero w 54 r. p.n.e., wykonanie zabiegu nie było więc możliwe zarówno w zgodzie $z$ prawem, jak i ze względu na ówczesna wiedzę medyczną ${ }^{16}$. Mimo problemów natury medycznej i prawnej sposób narodzin Cezara stał się elementem jego „legendy”. $Z$ tego powodu należy wziąć pod uwagę sugestię niektórych badaczy, że taki opis narodzin miał znaczenie propagandowe, pokazujac $\mathrm{w}$ ten sposób, że wódz nie narodził się jak zwykły człowiek ${ }^{17}$. W takim przypadku kwestię należy omawiać $z$ punktu widzenia propagandy, a nie medycyny czy prawa, które było jasne w tej materii.

Pierwsza pewna wzmianka na temat zdrowia Cezara dotyczy lat 85-82 p.n.e., gdy ukrywał się on przed Sullą. Zgodnie z przekazem Swetoniusza miał wtedy zapaść na czwartaczkę ${ }^{18}$, czyli malarię

${ }^{14}$ Plinius, Historia Naturalis VII, 7(47). Wzmianki na temat rzekomych narodzin Cezara za pomoca cesarskiego cięcia pojawiły się także około X w. (Suda k 1199)

${ }_{15}$ M. do Samiero Barroso, Post-mortem cesarean section and embryotomy: myth, medicine and gender in Greco-Roman Culture, "Acta medico-historica Adriatica" 2013, vol. XI, No. 1, s. 75-88. Por. Women and Gender in Medieval Europe. An Encyclopedia, ed. M. Schaus, New York-London 2006, s. 105; R. Blume nfeld-Ko sinski, Not of woman born: representations of caesarean birth of medieval and Renaissance, Ithaca-London 1990, s. 153.

$16 \mathrm{~S}$. Lurie, The changing motives of cesarean section from the ancient world to the twenty first century, „Archives of Gynecology and Obstetrics” 2005, vol. CCLXXI, s. 281-285. Por. S. Lurie, M. Glezerman, The history of cesarean technique, „American Journal of Obstetrics and Gynecology” 2003, vol. XXX, s. 1803-1806; A.L. Oppen heim, A cesarean section in the second millennium BC, „Journal of the History of Medicine and Allied Sciences” 1960, vol. XV, s. 292-294.

${ }_{17}$ P.W.J. van D o n ge n, Cesarean section- etymology and early history, „South African Journal of Obstetrics and Gynaecology" 2009, vol. XV, No. 2, s. 62-66.

${ }^{18}$ Suetonius, Divus Iulius 1. 
wywoływana przez pierwotniaka $z$ rodziny Plasmodium ${ }^{19}$. Przebieg choroby ani ewentualne powikłania nie koresponduja jednak $z$ objawami opisanymi w źródłach. Dodatkowo drgawki i bóle głowy miały wystapić dopiero pod koniec życia Cezara, nie można zatem łączyć ich $z$ chorobą przebytą w młodości.

Poza wspomnianym epizodem, który nie miał wpływu na jego późniejsze przypadłości, wszystko wskazuje na to, że wódz był zdrowy. Swetoniusz stwierdził: „cieszył się dobrym zdrowiem aż do ostatnich lat, kiedy nagle zaczął zapadać na omdlenia, a także doznawać lęków w czasie snu" ${ }^{20}$. Autorzy antyczni, nawet ci niechętni Cezarowi, sa zgodni co do tego, że był aktywny, uczestniczył w życiu swoich żołnierzy, spiąc w podobnych warunkach, jedzac to, co oni, znoszac podobne trudy ${ }^{21}$. Nawet po ukończeniu 50 lat był w stanie przepłynać ponad 200 metrów, czego miał dokonać w Zatoce Aleksandryjskiej, ratując w czasie bitwy ważne dokumenty ${ }^{22}$. Oczywiście należy brać pod uwagę to, że wzmianki tego rodzaju miały na celu ukazanie zdrowia, odwagi i innych pozytywnych cech Cezara. Miały więc wydźwięk propagandowy, niemniej jest raczej mało prawdopodobne, by wszystkie zostały zmyślone.

Wszystkie fragmenty dotyczace epizodów „epileptycznych” Gajusza Juliusza Cezara należy datować na okres po jego 50 urodzinach $^{23}$. W tekstach dotyczących wcześniejszych lat jego życia informacje na temat ataków się nie pojawiały. Sugerowałoby to, że raczej nie występowały, a przynajmniej, że nie dochodziło do nich $\mathrm{w}$ miejscach publicznych. Biorac pod uwage pozycję Cezara oraz jego licznych przeciwników politycznych, mało prawdopodobne jest przemilczenie przez nich tego typu ataków. Nieliczne wzmianki mówią o pogorszeniu się stanu zdrowia Cezara. Swetoniusz, Plutarch oraz Appian z Aleksandrii wspominali o nagłych omdleniach, atakach padaczki oraz kurczach ${ }^{24}$. Pojawiały się także fragmenty na temat zmiany osobowości oraz nietypowych zachowań wodza ${ }^{25}$.

${ }_{19}$ Choroby zakaźne i pasożytnicze, red. Z. Dziubek, Warszawa 2003, s. 459-464. Por. R.M. Fairhurst, T.E. Wellems, Plasmodium species (malaria), [w:] Mandell, Douglas, and Bennett's Principles and Practice of Infectious Diseases, eds G.L. Mandell, J.E. Bennett, R. Dolin, Philadelphia 2010, s. 3437-3462.

20 Su et onius, Divus Iulius 45.

${ }^{21}$ Su et o nius, Divus Iulius 66-68; P1uta r c h, Caesar XVII.

${ }^{22}$ Suetonius, Divus Iulius 65.

23 A. Kam m, op. cit., s. 19-150.

${ }^{24}$ Suetonius, Divus Iulius 45; P1utarch, Caesar XVII, LIII; A p pian, Bel. Civ. XIV, 110.

${ }^{25}$ Di o, 44.8.1-4. 
Pierwszy z ataków „epileptycznych” miał nastąpić w 49 r. p.n.e. w Kordobie ${ }^{26}$. Wódz miał wtedy 51 lat. Kolejny wspomniany w źródłach zdarzył się pod Tapsus w 46 r. p.n.e. ${ }^{27} \mathrm{~W}$ części źródeł odnajdujemy także wzmianki dotyczące sytuacji, w których Cezar odmówił stawienia się przed senatem, a wytłumaczeniem tego stanu rzeczy miał być jego stan zdrowia ${ }^{28}$. Rodzi się pytanie: czy nie były to próby maskowania nagłych ataków choroby, które mogłyby zostać zauważone przez senatorów, czy też stan zdrowia był wygodną wymówka, gdy wódz nie miał zamiaru ulegać naciskowi swoich oponentów ${ }^{29}$ ?

Chronologia pojawienia się pierwszych, odnotowanych ataków zdaje się także przeczyć teorii mówiącej, że Cezar cierpiał na epilepsję, znana już w antyku pod nazwą „świętej choroby”, chociaż Plutarch stwierdzał dobitnie, że: „cierpiał na bóle głowy, a przy tym jeszcze ulegał atakom padaczki”30. Określenie przypadłości wodza mianem padaczki mogło wynikać z ówczesnej wiedzy na temat objawów tej choroby. Epilepsja została opisana już przez Hipokratesa $^{31}$, w związu $z$ czym była znana i rozpoznawana w antycznym Rzymie. Nie zmienia to jednak faktu, że jako napady epileptyczne błędnie wówczas diagnozowano wiele innych jednostek chorobowych bądź ich objawów. Należy także wziąć pod uwagę to, że w starożytności epilepsja nie była postrzegana negatywnie, dlatego też plotki czy wzmianki na ten temat nie szkodziłyby Cezarowi ${ }^{32}$.

Epilepsja charakteryzuje się napadami wynikającymi z przewlekłych zaburzeń neurologicznych. Jest nieuleczalna, chociaż współcześnie w wielu przypadkach można dzięki lekom ją kontrolować ${ }^{33}$.

26 Plutarch, Caesar XVII, 2-4.

27 Plutarch, Caesar LII.

${ }^{28}$ Dio, 44.8; Suetonius, Divus Julius 84.1.

${ }^{29}$ Zdania w tej kwestii sa podzielone, szczególnie że autorzy antyczni wskazywali różne przypadłości będące powodem odmowy Cezara, np. Kasjusz Dion sugerował biegunkę (Dio, 44.8).

${ }^{30}$ Plutarch, Caesar XVII.

${ }^{31}$ Hip pocrates, On sacred disease, transl. F. Adams, Cambridge 1868. Por. D. Todman, Epilepsy in Graeco-Roman world: Hippocratic medicine and Asklepian temple medicine compared, "Journal of the History of the Neurosciences" 2008, vol. XVII, s. 435-441; F.P. Moog, A. Karen berg, Between Horror and Hope: Gladiator's Blood as a Cure for Epileptics in Ancient Medicine, „Journal of the History of the Neurosciences” 2003, vol. XII, s. 137-143.

${ }^{32}$ Z. Kazibutowska, A. Gołba, Geniusz i padaczka, „Aktualności Neurologiczne” 2010, t. X, nr 4, s. 190-193.

${ }^{33}$ D. Janz, H.-H. Frey, L. Beani, Antiepileptic drugs, Berlin-New York 1985. Por. N. Bernasconi, Is epilepsy a curable neurodegenerative disease?, „Brain” 
Epizody padaczkowe mają różne nasilenie: od prawie niezauważalnych po długie, silne wstrząsy. W większości przypadków etiologia choroby jest nieznana, chociaż wskazuje się na podłoże genetyczne, u wielu osób rozwija się na skutek urazu mózgu, jego udaru czy guza ${ }^{34}$. Biorac pod uwage przekazy dotyczace życia Cezara, nie mamy żadnych wzmianek sugerujących, że wódz doznał urazu mózgu lub udaru w wieku dorosłym ${ }^{35}$, watpliwe jest także, by ewentualna choroba miała podłoże genetyczne lub była efektem urazu w czasie narodzin. Gdyby tak było, ataki pojawiłyby się w okresie młodzieńczym. Nieco inaczej wygląda kwestia ewentualnego guza mózgu ${ }^{36}$. Nie da się potwierdzić ani wykluczyć, że wspomniane w źródłach ataki „epilepsji” nie były objawem padaczki, a właśnie efektem guza. Wiadomo, że około 30\% osób cierpiących na tę przypadłość ma padaczkę, prawdopodobieństwo choroby wzrasta, gdy nowotwór jest umiejscowiony $\mathrm{w}$ płacie skroniowym oraz w nowotworach charakteryzujacych się powolnym wzrostem ${ }^{37}$.

W literaturze przedmiotu pojawiały się także sugestie, że Cezar cierpiał na gruźlicę mózgu i opon mózgowo-rdzeniowych ${ }^{38}$. Nie-

2016, vol. CXXXIX, s. 2336-2337; G.K. Bergey, Neurostimulation in the treatment of epilepsy, „Experimental Neurology” 2013, vol. CCXLIV, s. 87-95.

${ }^{34}$ Pathophysiology of disease: an introduction to clinical medicine, eds S.J. McPhee, D. Gary, New York 2010. Por. A.L. Devlin, M. Ode11, J.L. Charlton, S. Koppe1, Epilepsy and driving: current status of research. „Epilepsy Research” 2012, vol. CII, s. 135-152; P. Tinuper, F. Provini, F. Bisulli, L. Vignatelli, G. Plazzi, R. Vetrugno, P. Montagna, E. Lugaresi, Movement disorders in sleep: guidelines for differentiating epileptic from non-epileptic motor phenomena arising from sleep, „Sleep Medicine Reviews” 2007, vol. XI, s. 255-267.

${ }^{35}$ Część badaczy uważa, że Cezar mógł doznać urazu głowy jako dorosły człowiek. Tezę postawiono na podstawie popiersia $z$ Tusculum, czyli jedynego zachowanego przedstawienia wodza, powstałym w czasie jego życia, a dowodem ma być brak asymetrii głowy. Por. F. Bru schi, op. cit., s. 373.

${ }^{36}$ L.M. DeAngelis, Brain tumors, "The New England Journal of Medicine” 2001, vol. CCCXLIV, s. 114-123.

${ }_{37}$ M. Maschio, Brain Tumor - Related Epilepsy, „Current Neuropharmacology” 2012, vol. X, s. 124-133. Por. A.O. Ros setti, R. Stupp, Epilepsy in brain tumor patients, „Current Opinion in Neurology” 2010, vol. XXIII, s. 603-609; J. Hildebrand, C. Lecaille, J. Perennes, J.Y. Delattre, Epileptic seizures during follow-up of patients treated for primary brain tumors, "Neurology” 2005, vol. LXV, s. 212-215.

${ }_{38}$ M. Korzeniewska-Koseła, Gruźlica ośrodkowego układu nerwowego, „Postępy Nauk Medycznych” 2007, t. XII, s. 563-565. Por. W. D rozdowski, J. Zajkowska, Gruźlica ośrodkowego układu nerwowego, „Polski Przegląd Neurologiczny" 2013, t. IX, s. 146-151; M. Henry, R.S. Holzman, Tuberculosis of the brain, meninges and spinal cord, [w:] Tuberculosis, eds W.N. Rom, S.M. Garay, 
leczona choroba prowadzi m.in. do nieodwracalnych uszkodzeń neurologicznych. Wśród objawów wymienia się znane $z$ przekazów antycznych dotyczacych Cezara: bóle głowy, wymioty czy drgaw$\mathrm{ki}^{39}$. W przypadku tej choroby obserwuje się także senność, światłowstręt, zaburzenia mowy czy niedowłady kończyn, czyli objawy trudne do ich niezauważenia, a jednak niewspominane w odniesieniu do wodza ${ }^{40}$. Dodatkowo nieleczona choroba jest w 100\% śmiertelna, przy czym zgon następuje stosunkowo szybko po wystapieniu objawów neurologicznych ${ }^{41}$. Jak wspomniałam, pierwszy $z$ ataków, na które cierpiał Cezar, nastąpił w 49 p.n.e., następny zaś w 46 p.n.e. Gdyby wódz cierpiał na gruźlicę mózgu, nie byłoby możliwości, by przez trzy lata objawy choroby ograniczyły się tylko do bólu głowy i drgawek ${ }^{42}$.

Wśród licznych chorób, na które zgodnie $z$ hipotezami licznych historyków i lekarzy miał cierpieć Gajusz Juliusz Cezar, znalazła się także choroba Meniera ${ }^{43}$. Atakuje ona przede wszystkim osoby w przedziale wiekowym 40-50 lat, dlatego biorac pod uwage wiek wodza w chwili, gdy zaczęto odnotowywać niepokojące objawy i ataki, część badaczy uznała ją za bardzo prawdopodobna przyczynę jego dolegliwości. Choroba jest jednak stosunkowo rzadka i nawet współcześnie nie do końca znamy jej przyczynę. U chorych obserwuje się nadmierne gromadzenie się i wzrost ciśnienia endolimfy w błędniku. Objawami sa m.in. zawroty głowy, szumy w uszach

R.S. Holzman, Philadelphia 2004, s. 445-464; J.J. Ke1ly, E.A. Horowitz, C.J. Destache, A.H. Fruin, V.A. Long, Diagnosis and treatment of complicated tubercular meningitis, „Pharmacotherapy” 1999, vol. XIX, s. 1167-1172.

${ }_{39}$ Plutarch, Caesar XVII; LII; Appian, Bel. Civ. XIV, 110.

40 Problematyczna jest wspominana przez niektórych badaczy kwestia obrażenia przez Cezara senatorów, których powitał na siedzaco, zamiast powstać. Niektórzy sugeruja, że nie było to celowe poniżenie członków senatu, a efekt czasowego niedowładu kończyn w wyniku mikrowylewu. Por. F.M. Gala s si, H. A s hrafian, Has the diagnosis..., s. 1521-1522.

${ }^{41}$ A.-S. Halkjaer Christensen, C. Roed, L.H. Omland, P.H. Anders e n, N. Obe1, A.B. Anders en, Long-Term Mortality in Patients with Tuberculous Meningitis: A Danish Nationwide Cohort Study, „PloS One” 2011, vol. VI, No. 11, s. $1-6$.

${ }^{42}$ K. Guziejko, P. Czupryna, A. Moniuszko, S. Grygorczuk, M. Kondrusik, J. Zajkowska, S. Pancewicz, Gruźlicze zapalenie opon rdzeniowo-mózgowych - opis przypadku, "Przegląd Epidemiologiczny” 2013, vol. LXVII, s. 717-719. Por. L.M. Leach, Acute and Critical Care Medicine at a Glance, Singapore 2010, s. 101.

${ }^{43}$ T. Cawthorne, Julius Caesar and the Falling Sickness..., s. 27-30. Por. S.H. Zaidi, A. Sin ha, Vertigo: A clinical guide, London 2013, s. 63-64. 
oraz utrata słuchu. Co ciekawe, po napadzie symptomy samoistnie ustępują. Problemem jest także niewystępowanie w jej przypadku części odnotowanych przez antycznych objawów. Wspominane przez autorów antycznych napady „epileptyczne” występuja jedynie w psiej odmianie choroby Maniera ${ }^{44}$, dodatkowo u Cezara nie odnotowywano problemów ze słuchem. Jedyna wzmianka na ten temat pojawia się nie w przekazach antycznych, a dopiero w utworze literackim - sztuce Szekspira ${ }^{45}$. Badaczom nie udało się odkryć, jakie było źródło tej informacji wplecionej w tekst przez słynnego dramatopisarza, w związku z czym nie możemy uznawać jej za wiążącą.

Część badaczy wskazuje raczej na choroby bakteryjne lub pasożytnicze jako te stojace za objawami wspominanymi przez antycznych. Za tego typu chorobami przemawia także moment wystąpienia objawów. Większość wspomnianych schorzeń albo nie spełniała kryterium dotyczącego wymienionych objawów, albo ich przebieg jest na tyle gwałtowny, że w stosunkowo krótkim czasie prowadza do zgonu.

Wśród wielu jednostek chorobowych, które „diagnozowano” u Cezara na podstawie przekazów antycznych, wymieniano także neurosyfilis, czyli kiłę mózgowo-rdzeniową ${ }^{46}$. Objawy sa zależne od umiejscowienia choroby. W przypadku nacieków u podstawy mózgu występuja m.in. bóle głowy, a gdy nastąpi zajęcie dużych naczyń, dochodzi do napadów padaczkowych, niedowładów i afazji. Co ciekawe, w przypadku nieleczonego syfilisu wspomniane objawy pojawiaja się zazwyczaj 10-20 lat po zakażeniu bakteria Treponema pallidum pallidum. Choroba jest przenoszona droga płciową, co biorąc pod uwage szeroko omawianą w źródłach roz-

${ }^{44}$ M. Kent, S.R. Platt, S.J. Schatzberg, The neurology of balance: Function and dysfunction of the vestibular system in dogs and cats, "The Veterinary Journal" 2010, vol. CLXXXV, s. 247-258.

${ }^{45}$ W. Shakes peare, Juliusz Cezar, przekł. M. Słomczyński, Kraków 2000, s. 15, akt 1, scena 1: „to ucho mam głuche, więc przejdź na prawo/ I powiesz szczerze, jaki masz sąd o nim?"

${ }^{46}$ L.J. Britton, B.E. Joyner, A.H. Ewart, Neurosyphilis: not to be forgotten, „Internal Medicine Journal” 2004, vol. XXXIV, s. 299-300. Por. C. G ürs es, M. Kürtüncü, J. Jirsch, N. Yeşilot, H. Hanağasi, N. Bebek, B. Baykan, M. Emre, A. Gökyiğit, F. Andermann, Neurosyphilis presenting with status epilepticus, „Epileptic Disorders” 2007, vol. IX, s. 51-56; A. Heald, S. Connolly, P. Hudgson, Neurosyphilis presenting as complex partial status epilepticus, „European Neurology” 1996, vol. XXXVI, s. 111-112. 
wiązłość seksualną Cezara, czyniłoby zarażenie bardzo prawdopodobnym. Problematyczna w tym przypadku może być chronologia pojawienia się choroby w Europie. Do dziś wśród badaczy nie ma zgody co do pochodzenia syfilisu ${ }^{47}$. Część uważa, że choroba dotarła na kontynent europejski dopiero w XV w., przywieziona $z$ Nowego Świata ${ }^{48}$, a upowszechniła się w kolejnym stuleciu. Inni sądza, że była obecna w Europie jeszcze przed czasami wielkich odkryć geograficznych. Jej symptomy miały zostać opisane przez słynnego greckiego medyka Hipokratesa. Teorię miały także potwierdzać szkielety odkryte w Pompejach oraz Metaponto w Italii ze zmianami podobnymi do tych wywoływanych przez syfilis. Mimo grupy zwolenników teoria dotycząca prekolumbijskiego pochodzenia choroby nie została udowodniona, należałoby odrzucić hipotezę sugerująca, że Cezar mógł cierpieć $z$ jej powodu.

Zdecydowanie bardziej prawdopodobna przyczyna jego napadów jest sugerowane przez niektórych zakażenie Taenia solium, czyli tasiemcem uzbrojonym. Do zakażenia mogło dojść w czasie pobytu polityka w Egipcie. Na podstawie papirusów medycznych oraz badań przeprowadzonych na mumiach udowodniono, że zakażenia pasożytami wewnętrznymi były nad Nilem stosunkowo powszechne ${ }^{49}$. Wiadomo także, że tasiemiec miał zdolność osadzania larw w gałce ocznej oraz mózgu. Wywoływany przez nie ucisk mózgu potrafi wywoływać objawy podobne do padaczki, silne bóle głowy, nudności, a nawet zaburzenia zachowania. Badacze zwrócili

${ }^{47}$ M.E. Kent, F. Rom anelli, Reexamining syphilis: an update on epidemiology, clinical manifestations, and management, "Annals of Pharmacotherapy" 2008, vol. XLII, s. 226-36.

${ }^{48}$ D. Farhi, N. Dupin, Origins of syphilis and management in the immunocompetent patient: facts and controversies, "Clinics in dermatology” 2010, vol. XXVIII, s. 533-538. Por. B.M. Rothschild, F.L. Calderon, A. Coppa, Ch. Rothschild, First European Exposure to Syphilis: The Dominican Republic at the Time of Columbian Contact, "Clinical Infectious Diseases” 2000, vol. XXXI, s. 936-941.

${ }^{49}$ Mummies, diseases and Ancient Cultures, eds A. Cockburn, E. Cockburn, T.A. Reyman, Cambridge 1998, s. 40. Por. M. Henneberg, R.J. Henneberg, Reconstructing Medical Knowledge in Ancient Pompeii from the Hard Evidence of Bones and Teeth, [w:] Homo Faber: Studies on Nature. Technology and Science at the Time of Pompeii, eds J. Renn, G. Castagnetti, Rome 2002, s. 169-187. Por. M. Henneberg, R.J. Henneberg, Treponematosis in an Ancient Greek colony of Metaponto, Southern Italy 580-250 BCE, [w:] The Origin of Syphilis in Europe, Before or After 1493?, eds O. Dutour, G. Plafi, J. Berato, J.-P. Brun, Toulon-Paris 1994 , s. 92-98. 
uwagę na możliwość zarażenia pasożytem ze względu na chronologię wystąpienia ataków. Jeden $z$ odnotowanych napadów nastąpił w 46 r. p.n.e. pod Thapsus, czyli rok po pobycie Cezara w Egipcie.

W związku $z$ tą teoria oraz biorąc pod uwagę pozostałe objawy, w 2016 r. włoski badacz Fabio Imparato wysunał bardzo ciekawa tezę. Zasugerował, że epileptyczne ataki zauważone u wodza mogły być wynikiem celiakii ${ }^{50}$ - autoimmunologicznej choroby o podłożu genetycznym. Charakteryzuje się ona nietolerancja glutenu, białka zapasowego zawartego w zbożach, m.in. pszenicy, życie, jęczmieniu czy owsie. Współczesne badania pokazuja, że choroba może się uaktywnić w każdym wieku, a wśród objawów wymienia się wzdęcia, ból brzucha, przewlekle biegunki, niedokrwistość czy przewlekłe zmęczenie. Biorąc pod uwagę $z$ jednej strony opisywane w literaturze antycznej ataki, a $z$ drugiej dużą aktywność Cezara, trudno zgodzić się $z$ tym, że celiakia mogła być chorobą, na która cierpiał wódz.

Wśród wielu, czasem nieco „egzotycznych”, diagnoz pojawiła się także niezwykle interesująca sugestia, że Cezar oraz osoby z jego rodu cierpiały na dziedziczne autosomalnie recesywne zaburzenie transportu aminokwasów obojętnych (tryptofan) w świetle jelita i kanalikach nerkowych ${ }^{51}$ - we współczesnej literaturze nazywanej choroba Hartnupów ${ }^{52}$. Chorobie towarzysza dwie grupy objawów: 1) skórne, jak rumień skórny, oraz 2) zwiąane $z$ układem nerwowym, jak ataksja, czyli problemy z koordynacją ruchowa, trudności $z$ mową, bezsenność, zmiany nastroju, omamy i halucynacje oraz drżenie mięśni. Co istotne, objawy pojawiaja się już w dzieciństwie, utrzymuja się kilka tygodni, po czym znikaja. Ataki moga nawracać co kilka lat, ale im starsza osoba, tym pojawiaja się częściej. Nieregularność ataków oraz zwiększenie ich częstotliwości w późniejszym wieku do pewnego stopnia wyjaśniałoby, czemu w przypadku Cezara objawy zaczęły być zauważane stosunkowo późno. W okresie, gdy zaczęto wspominać o atakach, Gajusz

${ }^{50}$ F. Imparato, Celiac Disease Could Have Been the Cause of Caesar's Epilepsy, „Journal of Clinic Gastroenterology” 2016, vol. L, s. 797.

${ }^{51}$ Mutacja genetyczna obecna $u$ chorych utrudnia wchłanianie $z$ przewodu pokarmowego tryptofanu, co hamuje zdolność do wytwarzania witaminy B3.

52 J. Bielen berg, Das julisch-claudische Kaiserhaus und das Hartnup-Syndrom. Geenetisch bedingte Störungen des Tryptophanstoffwechsels, „Ärztezeitschrift für Naturheilverfahren" 2004, Bd. XLV, Nr. 7, s. 466-470. Por. J.H. Dir ckx, Julius Caesar and the Julian Emperors. A Family Cluster with Hartnups Disease?, „The American Journal of Dermatopathology” 1986, vol. VIII, No. 4, s. 351-357. 
Juliusz Cezar był już osoba powszechnie znana, stale obecną na scenie politycznej, trudno więc było nie dostrzec ataków czy zmian $\mathrm{w}$ zachowaniu. W młodości pozostawał przez pewien czas $\mathrm{w}$ cieniu, co mogło wpłynąc na brak wzmianek o ewentualnych atakach, szczególnie że w przypadku tej choroby nie występowały one regularnie. Dodatkowo w leczeniu i łagodzeniu objawów choroby niezwykle istotna jest dieta bogata w witaminę B3, dlatego okresowo chory mógł nie mieć objawów, jeśli dzięki posiłkom uzupełniał niedobory witaminy ${ }^{53}$.

Niezwykle interesujace wzmianki dotyczace zdrowia krewnych Cezara, a szczególnie odnotowana przez Pliniusza nagła śmierć jego ojca, której przyczyna prawdopodobnie był udar, a także objawy, które zaobserwowano w Kordobie i pod Tapsus, czyli bóle głowy, vertigo oraz zawroty głowy, powodują, że część sugerowanych przez badaczy chorób staje się mało prawdopodobna, szczególnie jeśli odwołamy się do sytuacji dotyczącej witania senatorów w pozycji siedzącej. Zauważono, że zachowanie wodza mogło wynikać z czasowego niedowładu kończyn będącego jednym $z$ objawów wylewu ${ }^{54}$. Dlatego właśnie, biorąc pod uwage przekazy autorów antycznych oraz historię rodziny Gajusza Juliusza Cezara, a także współczesna wiedzę medyczna, zdecydowana większość badaczy za najbardziej prawdopodobna przyczynę choroby atakujacej wodza uznaje guz mózgu lub serię mikroudarów, których objawy ustępują po pewnym czasie (od kilku minut do kilku godzin). Ataki sklasyfikowane

${ }^{53} \mathrm{~W}$ diecie osób cierpiących na chorobę Hartnupów powinny się znajdować m.in. ryby, mięso, drób, cielęcina, wątróbka, zboża, kasze, produkty pełnoziarniste, otręby pszenne, jajka itd. Większość wspomnianych produktów była bardzo popularna w diecie starożytnych Rzymian, szczególnie tych $z$ warstw wyższych. Więcej na temat diety w antyku por. M. Kokoszko, K. Jagusiak, Z. Rzeźnicka, Kilka słów o zupie zwanej ptisane, "Zeszyty Wiejskie” 2013, t. XVIII, s. 282-292; e oru ndem, Owies $w$ greckich traktatach medycznych starożytności i Bizancjum (V w. prz. Chr. - XI w. po Chr.), „Vox Patrum” 2013, t. LIX, s. 421-447; M. Kokoszko, K. Jagusiak, Zboża Bizancjum. Kilka uwag na temat roli produktów zbożowych na podstawie źródeł greckich, „Zeszyty Wiejskie” 2012, t. XVII, s. 19-38; M. Kokoszko, Z. Rzeźnicka, Dietetyka w „De re coquinaria”, „Przegląd Nauk Historycznych” 2011, t. X, nr 2, s. 5-25; M. Kokoszko, Sosy w kuch-

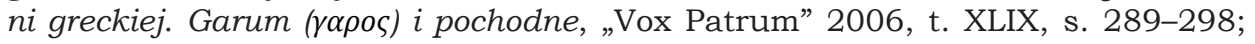
id e m, Ryby i ich znaczenie $w$ życiu codziennym ludzi późnego antyku i wczesnego Bizancjum (III-VII w.), Łódź 2005.

${ }^{54}$ L. Gao, J.F. Meschia, S.E. Judd et al., What stroke symptoms tell us: association of risk factors and individual stroke symptoms in the Reasons for Geographic And Racial Differences in Stroke (REGARDS) study, „Journal of Stroke and Cerebrovascular Diseases" 2012, vol. XXI, s. 411-416. 
przez antycznych jako epilepsja mogły być jedynie objawem wywoływanym przez ucisk guza na mózg lub krótkotrwałym efektem małego udaru. Niemniej szczególnie w kontekście szeroko rozumianego rodu Juliuszów niezwykle ciekawa i warta dalszej analizy jest pojawiająca się w literaturze sugestia dotycząca choroby Hartnupów jako przypadłości „gnębiącej” Cezara oraz jego ród.

Jednoznaczne ustalenie choroby, na która cierpiał Gajusz Juliusz Cezar, nigdy nie będzie w pełni możliwe. Nie dysponujemy materiałem kostnym, który można by poddać serii badań, mamy jedynie przekazy pisane. Sa one mocno fragmentaryczne, pisane przez osoby niemające wykształcenia medycznego. Dodatkowo należy założyć, że w przekazach odnotowano jedynie te sytuacje, w których objawów nie dało się ukryć i zobaczyły je osoby postronne. Powoduje to, że zachował się jedynie drobny wycinek $z$ wachlarza objawów, niepozwalający stworzyć klarownego obrazu. Trudno także jednoznacznie jako efekty choroby interpretować niektóre poczynania wodza, ponieważ mogło to być jedynie usprawiedliwienie pewnego typu zachowania - i to nawet niedokonywane przez samego Cezara czy jego otoczenie, a jego potomnych, stykajacych się z kreowana m.in. przez Oktawiana Augusta legenda wodza, a nie $z$ nim samym.

\section{Bibliografia}

\section{Ź́nóDEA DRUKOWANE}

Appian, Bel. Civ.

Appian, Roman History, vol. IV (Civil Wars, Books 1-2), transl. B. McGing, Cambridge 2020.

Dio

Dio Cassius, Roman History, vol. IV (Books 41-45), transl. E. Cary, H.B. Foster, Cambridge 1916.

Hippocrates, On sacred disease, transl. F. Adams, Cambridge 1868.

Plinius, Historia Naturalis

Pliny, Natural History, vol. II (Books 3-7), transl. H. Rackham, Cambridge 1942. Plutarch, Caesar

Plutarch, Lives, vol. VII (Demosthenes and Cicero. Alexander and Caesar), transl. B. Perrin, Cambridge 1919. 
Suetonius, Divus Iulius

Suetonius, Lives of the Caesars, vol. I (Julius, Augustus, Tiberius, Gaius, Caligula), transl. J.C. Rolfe, Cambridge 1914.

\section{OpRacowania}

Bergey G.K., Neurostimulation in the treatment of epilepsy, „Experimental Neurology" 2013, vol. CCXLIV, s. 87-95.

Bernasconi N., Is epilepsy a curable neurodegenerative disease?, „Brain” 2016, vol. CXXXIX, s. 2336-2337.

Bielenberg J., Das julisch-claudische Kaiserhaus und das Hartnup-Syndrom. Geenetisch bedingte Störungen des Tryptophanstoffwechsels, „Ärztezeitschrift für Naturheilverfahren" 2004, Bd. XLV, Nr. 7, s. 466-470.

Blumenfeld-Kosinski R., Not of woman born: representations of caesarean birth of medieval and Renaissance, Ithaca-New York 1990.

Britton L.J., Joyner B.E., Ewart A.H., Neurosyphilis: not to be forgotten, „Internal Medicine Journal" 2004, vol. XXXIV, s. 299-300.

Bruschi F., Was Julius Caesar's epilepsy due to neurocysteriosis?, „Trends in Parasitology" 2011, vol. XXVII, s. 373-374.

Canfora L., Julius Caesar: People's Dictator, Edinburgh 2005.

Cawthorne N., Julius Caesar, London 2005.

Cawthorne T., Julius Caesar and the Falling Sicknes, „Proceedings of the Royal Society of Medicine" 1957, vol. LI, s. 27-30.

Choroby zakaźne i pasożytnicze, red. Z, Dziubek, Warszawa 2003, s. 459-464.

DeAngelis L.M., Brain tumors, „The New England Journal of Medicine” 2001, vol. CCCXLIV, s. 114-123.

Devlin A.L., Odell M., Charlton J.L., Koppel S., Epilepsy and driving: current status of research, „Epilepsy Research” 2012, vol. CII, s. 135-152.

Dirckx J.H., Julius Caesar and the Julian Emperors. A Family Cluster with Hartnups Disease?, „The American Journal of Dermatopathology” 1986, vol. VIII, No. 4, s. 351-357.

Do Samiero Barroso M., Post-mortem cesarean section and embryotomy: myth, medicine and gender in Greco-Roman Culture, "Acta medico-historica Adriatica" 2013, vol. XI, No. 1, s. 75-88.

Donnadieu B.-P., La prétendue épilepsie de Jules César, „Mémoires de la Société Nationale des Antiquaries de France” 1937, t. LXXX, s. 27-36.

Drozdowski W., Zajkowska J., Gruźlica ośrodkowego układu nerwowego, „Polski Przegląd Neurologiczny" 2013, t. IX, s. 146-151.

Fairhurst R.M., Wellems T.E., Plasmodium species (malaria), [w:] Mandell, Douglas, and Bennett's Principles and Practice of Infectious Diseases, eds G.L. Mandell, J.E. Bennett, R. Dolin, Philadelphia 2010, s. 3437-3462.

Farhi D., Dupin N., Origins of syphilis and management in the immunocompetent patient: facts and controversies, „Clinics in dermatology” 2010, vol. XXVIII, s. 533-538. 
Ferreira Camargo C.H., Ghizoni Teive H.A., Searching for neurological diseases in the Julio-Claudian dynasty of the Roman Empire, "Arquivos de Neuro-Psiquiatria" 2018, vol. LXXVI, No. 1, s. 53-57.

Freeman P., Julius Caesar, New York 2008.

Galassi F.M., Ashrafian H., Has the diagnosis of a stroke been overlooked in the symptoms of Julius Caesar?, „Neurological Science” 2015, vol. XXXVI, s. $1521-1522$.

Galassi F.M., Ashrafian H., Julius Caesar's Disease: a new diagnosis, London 2016.

Galassi F.M., Ashrafian H., Julius Caesar's Disease: a new diagnosis, „Neurological Sciences” 2017, vol. XXVIII, s. 1-2.

Gao L., Meschia J.F., Judd S.E., Muntner P., McClure L.A., Howard V.J., Rhodes J.D., Cusham M., Safod M.M., Soliman E.Z., Kleindorfer D.O., Howard G., What stroke symptoms tell us: association of risk factors and individual stroke symptoms in the Reasons for Geographic And Racial Differences in Stroke (REGARDS) study, „Journal of Stroke and Cerebrovascular Diseases” 2012, vol. XXI, s. 411-416.

Gelzer M., Caesar Politician and Statesman, Cambridge 1967.

Gomez J.G., Kotler J.A., Long J.B., Was Julius Caesar's epilepsy due to a brain tumor?, "Journal of the Florida Medical Association" 1995, vol. LXXXII, s. $199-201$.

Gürses C., Kürtüncü M., Jirsch J., Yeşilot N., Hanağasi H., Bebek N., Baykan B., Emre M., Gökyiğit A., Andermann F., Neurosyphilis presenting with status epilepticus, „Epileptic Disorders” 2007, vol. IX, s. 51-56.

Guziejko K., Czupryna P., Moniuszko A., Grygorczuk S., Kondrusik M., Zajkowska J., Pancewicz S., Gruźlicze zapalenie opon rdzeniowo-mózgowych - opis przypadku, „Przegląd Epidemiologiczny” 2013, t. LXVII, s. 717-719.

Halkjaer Christensen A.S., Roed C., Omland L.H., Andersen P.H., Obel N., Andersen A.B., Long-Term Mortality in Patients with Tuberculous Meningitis: A Danish Nationwide Cohort Study, „PloS One” 2011, vol. VI, No. 11, s. 1-6.

Heald A., Connolly S., Hudgson P., Neurosyphilis presenting as complex partial status epilepticus, „European Neurology” 1996, vol. XXXVI, s. 111-112.

Henneberg M., Henneberg R.J., Reconstructing Medical Knowledge in Ancient Pompeii from the Hard Evidence of Bones and Teeth, [w:] Homo Faber: Studies on Nature. Technology and Science at the Time of Pompeii, eds J. Renn, G. Castagnetti, Rome 2002, s. 169-187.

Henneberg M., Henneberg R.J., Treponematosis in an Ancient Greek colony of Metaponto, Southern Italy 580-250 BCE, [w:] The Origin of Syphilis in Europe, Before or After 1493?, eds O. Dutour, G. Plafi, J. Berato, J.-P. Brun, ToulonParis 1994, s. 92-98.

Henry M., Holzman R.S., Tuberculosis of the brain, meninges and spinal cord, [w:] Tuberculosis, eds W.N. Rom, S.M. Garay, R.S. Holzman, Philadelphia 2004, s. 445-464.

Hildebrand J., Lecaille C., Perennes J., Delattre J.Y., Epileptic seizures during follow-up of patients treated for primary brain tumors, „Neurology” 2005, vol. LXV, s. 212-215. 
Hughes J.R., Dictator Perpetuus: Julius Caesar - did he have seizures? If so, what was the etiology? „Epilepsy and Behaviour” 2004, vol. V, s. 756-764.

Imparato F., Celiac Disease Could Have Been the Cause of Caesar's Epilepsy, „Journal of Clinic Gastroenterology” 2016, vol. L, s. 797.

Janz D., Frey H.-H., Beani L., Antiepileptic drugs, Berlin-New York 1985.

Julius Caesar as Artful Reporter. The War Commentaries as Political Instruments, eds K. Welch A. Powell, Swansea 1998.

Kamm A., Julius Caesar. A Life, London-New York 2006.

Katz R.S., The Illness of Caligula, „The Classical World” 1972, vol. LXV, s. 223-225.

Kazibutowska Z., Gołba A., Geniusz i padaczka, „Aktualności Neurologiczne” 2010, t. X, nr 4, s. 190-193.

Keaveney A., Sulla the Last Republican, London-New York 2005.

Kelly J.J., Horowitz E.A., Destache C.J., Fruin A.H., Long V.A., Diagnosis and treatment of complicated tubercular meningitis, „Pharmacotherapy" 1999, vol. XIX, s. 1167-1172.

Kent M.E., Romanelli F., Reexamining syphilis: an update on epidemiology, clinical manifestations, and management, "Annals of Pharmacotherapy” 2008, vol. XLII, s. 226-236.

Kent M., Platt S.R., Schatzberg S.J., The neurology of balance: Function and dysfunction of the vestibular system in dogs and cats, "The Veterinary Journal” 2010, vol. CLXXXV, s. 247-258.

Kokoszko M., Ryby i ich znaczenie $w$ życiu codziennym ludzi późnego antyku i wczesnego Bizancjum (III-VII w.), Łódź 2005.

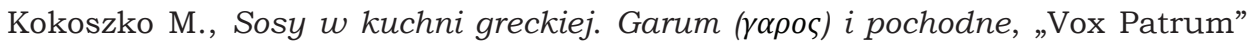
2006, t. XLIX, s. 289-298.

Kokoszko M., Jagusiak K., Zboża Bizancjum. Kilka uwag na temat roli produktów zbożowych na podstawie źródeł greckich, „Zeszyty Wiejskie” 2012, t. XVII, s. $19-38$.

Kokoszko M., Jagusiak K., Rzeźnicka Z., Kilka słów o zupie zwanej ptisane, „Zeszyty Wiejskie” 2013, t. XVIII, s. 282-292.

Kokoszko M., Jagusiak K., Rzeźnicka Z., Owies $w$ greckich traktatach medycznych starożytności i Bizancjum (V w. prz. Chr. - XI w. po Chr.), „Vox Patrum” 2013, t. LIX, s. 421-447.

Kokoszko M., Rzeźnicka Z., Dietetyka w „De re coquinaria”, „Przegląd Nauk Historycznych" 2011, t. X, nr 2, s. 5-25.

Korzeniewska-Koseła M., Gruźlica ośrodkowego układu nerwowego, „Postępy Nauk Medycznych" 2007, t. XII, s. 563-565.

Leach L.M., Acute and Critical Care Medicine at a Glance, Singapore 2010.

Lurie S., The changing motives of cesarean section from the ancient world to the twenty first century, „Archives of Gynecology and Obstetrics” 2005, vol. CCLXXI, s. 281-285.

Lurie S., Glezerman M., The history of cesarean technique, „American Journal of Obstetrices and Gynecology" 2003, vol. XXX, s. 1803-1806. 
Maschio M., Brain Tumor-Related Epilepsy, „Current Neuropharmacology” 2012, vol. X, s. 124-133.

Meier Ch., Caesar: A Biography, New York 1996.

Moog F.P., Karenberg A., Between Horror and Hope: Gladiator's Blood as a Cure for Epileptics in Ancient Medicine, „Journal of the History of the Neurosciences” 2003, vol. XII, s. 137-143.

Morgan M.G., Caligula's Illness Again, „The Classical World” 1973, vol. LCVI, s. 327-329.

Mummies, diseases and Ancient Cultures, eds A. Cockburn, E. Cockburn, T.A. Reyman, Cambridge 1998.

Oppenheim A.L., A cesarean section in the second millennium BC, „Journal of the History of Medicine and Allied Sciences" 1960, vol. XV, s. 292-294.

Osgood J., The Pen and the Sword: Writing and Conquest in Caesar's Gaul, "Classical Antiquity" 2009, vol. XXVIII, No. 2, s. 328-358.

Pathophysiology of disease: an introduction to clinical medicine, eds S.J. McPhee, D. Gary, New York 2010.

Retief F.P., Cilliers J.F.G., Julius Caesar (100-44 BC) - did he have a brain tumor?, „South African Medical Journal” 2010, vol. C, s. 26-28.

Rossetti A.O., Stupp R., Epilepsy in brain tumor patients, „Current Opinion in Neurology" 2010, vol. XXIII, s. 603-609.

Rothschild B.M., Calderon F.L., Coppa A., Rothschild Ch., First European Exposure to Syphilis: The Dominican Republic at the Time of Columbian Contact, "Clinical Infectious Diseases” 2000, vol. XXXI, s. 936-941.

Sandison A.T., The Madness of the Emperor Caligula, „Medical History” 1958, vol. II, s. 202-209.

Shakespeare W., Juliusz Cezar, przekł. M. Słomczyński, Kraków 2000.

Stevenson T., Julius Caesar and the transformation of the Roman Republic, London-New York 2015.

Telford L., Sulla: A Dictator Reconsidered, Barnsley 2014.

Thomas Benediktson D., Caligula's Phobias and Philias: Fear of Seizure?, „The Classical Journal" 1991, s. 159-163.

Tinuper P., Provini F., Bisulli F., Vignatelli L., Plazzi G., Vetrugno R., Montagna P., Lugaresi E., Movement disorders in sleep: guidelines for differentiating epileptic from non-epileptic motor phenomena arising from sleep, „Sleep Medicine Reviews" 2007, vol. XI, s. 255-267.

Todman D., Epilepsy in Graeco-Roman world: Hippocratic medicine and Asklepian temple medicine compared, „Journal of the History of the Neurosciences” 2008, vol. XVII, s. 435-441.

Van Dongen P.W.J., Cesarean section - etymology and early history, „South African Journal of Obstetrics and Gynaecology" 2009, vol. XV, No. 2, s. 62-66.

Women and Gender in Medieval Europe. An Encyclopedia, ed. M. Schaus, New York-London 2006.

Zaidi S.H., Sinha A., Vertigo: A clinical guide, London 2013. 
NotKa O AUTORCE:

Dr Agnieszka Bartnik - adiunkt w Instytucie Historii Uniwersytetu Ślasskiego.

Zainteresowania naukowe: weterynaria antyczna, zależności między medycyną a weterynaria $\mathrm{w}$ antyku, diagnostyka i jednostki chorobowe znane $\mathrm{w}$ antyku, zastosowanie roślin, minerałów oraz substancji pochodzenia zwierzęcego w kuracjach weterynaryjnych, recepcja antycznych tradycji weterynaryjnych w średniowieczu.

ㄱavnieszka.bartnik@us.edu.pl 